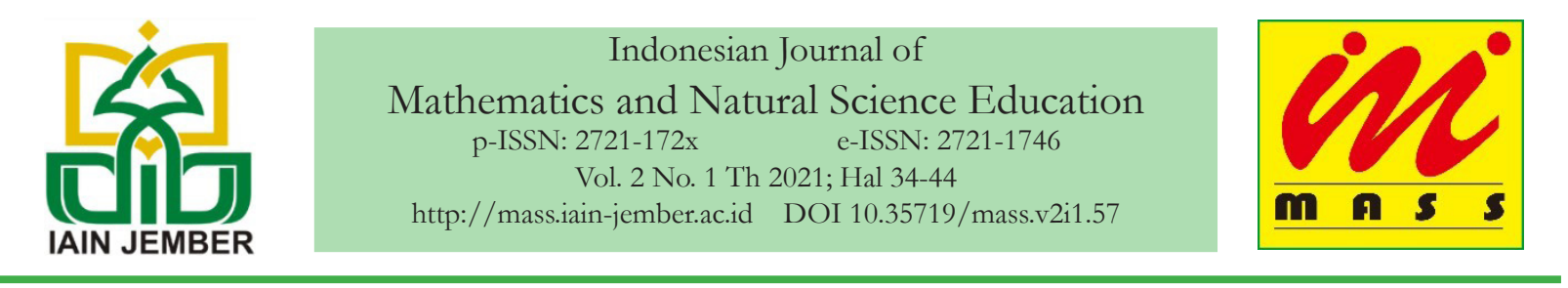

\title{
Pengembangan Modul Digital sebagai Bahan Ajar Biologi untuk Siswa Kelas XI IPA
}

\author{
Imro'atul Khasanah ${ }^{1}$, Ira Nurmawati ${ }^{*}$ \\ ${ }^{1}$ Program Studi Tadris Biologi, FTIK, IAIN Jember \\ * E-mail: nurmawati ira@yahoo.com
}

\begin{abstract}
Abstrak
Penelitian ini bertujuan mendeskripsikan pengembangan modul digital sebagai bahan ajar biologi untuk siswa kelas XI IPA di MAN 2 Jember Tahun Pelajaran 2019/2020 dan mendeskripsikan kevalidan modul digital sebagai bahan ajar biologi untuk siswa kelas XI IPA di MAN 2 Jember Tahun Pelajaran 2019/2020. Penelitian ini merupakan jenis penelitian dan pengembangan (Research and Development) dengan pendekatan model ADDIE (Analyze, Design, Development, Implementation, Evaluation). Tahap pada penelitian ini hanya sampai tahap Development karena keterbatasan kondisi pandemi Covid-19. Sehingga tidak memungkinkan untuk dilakukannya tahap implementasi dan evaluasi. Modul digital yang dikembangkan masih sebatas uji kevalidan produk yang melibatkan lima validator, yaitu dua orang ahli materi, dua orang ahli media, dan satu orang ahli desain pembelajaran. Adapun instrumen yang digunakan dalam penelitian ini berupa angket yang kemudian hasil angketnya dianalisis secara deskriptif kuantitatif. Berdasarkan analisis data, hasil validasi dari ahli materi sebesar $97,35 \%$, ahli media sebesar $89 \%$, ahli desain pembelajaran sebesar $80,5 \%$, berdasarkan kriteria validitas yang digunakan bahwa nilai tersebut dikategorikan sangat valid, dengan demikian dapat disimpulkan bahwa bahan ajar yang dikembangkan berupa modul digital sangat valid sebagai bahan ajar biologi siswa kelas XI IPA.
\end{abstract}

Kata Kunci: ADDIE, Bahan Ajar Biologi, Modul Digital

\section{PENDAHULUAN}

Pendidikan memiliki peranan yang sangat penting dalam menciptakan sumber daya manusia yang berkualitas guna mencapai cita-cita nasional. Melalui pendidikan pula, dapat menjadikan individu menjadi bermanfaat baik untuk diri sendiri, bangsa, maupun negara. Keberhasilan pendidikan tidak terlepas dari baik buruknya proses pembelajaran yang dilakukan di sekolah.

Proses pembelajaran merupakan proses mengatur, mengorganisasi lingkungan yang ada di sekitar peserta didik sehingga dapat menumbuhkan dan mendorong peserta didik melakukan proses belajar (Pane dan Dasopang, 2017). Pembelajaran juga dapat dikatakan sebagai suatu bimbingan atau bantuan dari guru kepada peserta didik dalam proses belajar.

Dalam rangka menciptakan suasana belajar yang menyenangkan dan menarik bagi siswa, seorang guru haruslah memiliki kemampuan untuk merancang pembelajaran, menerapkan model pembelajaran dan meyediakan bahan ajar yang menarik minat belajar siswa.

Biologi adalah salah satu cabang ilmu pengetahuan alam yang mempelajari tentang makhluk hidup, mulai dari 
struktur, fungsi serta perkembangan dari makhluk hidup tersebut, lebih dari itu, melalui biologi siswa juga mempelajari tentang sistem koordinasi dan alat indera, sistem reproduksi dan sistem imun. Ilmu biologi akan mudah dipelajari secara mandiri oleh semua siswa tingkat menengah atas jika dibantu oleh adanya bahan ajar yang berupa modul.

Dalam pengertian umum, modul adalah standar atau satuan pengukur. Dalam konteks pendidikan, modul adalah paket atau progam belajar mengajar, mulai dari perencanaan, pelaksanaan, sampai ke evaluasi terhadap dampak hasil pelaksanaan (Rahardi, 2005) Modul adalah materi ajar yang dipersiapkan untuk proses belajar mandiri (Prawiradilaga dan Chaeruman, 2018). Definisi lain modul adalah suatu paket pengajaran yang berkenaan dengan satu unit terkecil bertahap dari suatu pelajaran tertentu. Adapun maksud bertahap, sebab modul dipelajari secara individual dari satu sub bab ke sub bab lainnya (Asmi, 2018). Jika disimpulkan, modul adalah suatu paket pengajaran yang berisi dari beberapa sub bab yang dipersiapkan untuk proses belajar mandiri.

Menurut Rahdiyanta dalam Ramadhani (2020) modul memiliki karakteristik sebagai berikut:

a. Self instructional merupakan karakteristik yang memungkinkan pelajar dapat belajar secara mandiri.

b. Self contained, merupakan karakteristik modul yang memuat utuh seluruh materi pembelajaran yang dibutuhkan. Sehingga peserta didik dapat belajar tuntas sampai akhir pembelajaran.

c. Stand alone (berdiri sendiri), merupakan karakteristik modul yang tidak bergantung pada bahan ajar lain.

d. Adaptif, modul harus dapat menyesuaikan dengan perkembangan ilmu pengetahuan dan teknologi, sehingga modul tetap up to date.

e. User friendly, modul harus fleksibel yaitu bersifat mempermudah peserta didik dalam menyerap ilmu pengetahuan, salah satunya adalah dengan memakai bahasa yang mudah dimengerti.

Seiring berkembangnya ilmu pengetahuan dan teknologi, modul mulai bertransformasi menjadi modul digital, yaitu modul yang bisa diakses melalui laptop, komputer dan lainya. Modul digital ini berwujud teks, gambar, video dan audio. Modul digital ini tidak membutuhkan ongkos untuk perbaikan fisik modul, dan modul digital ini sangat cocok dimanfaatkan untuk sistem belajar jarak jauh dan dapat membantu untuk belajar mandiri.

Modul digital yang dimaksudkan adalah bahan ajar pendidik atau peserta didik secara mandiri melalui modul yang dibuat secara digital melalui software FlipBook yaitu Kvisoft FlipBook Maker Pro dan Adobe Flash CS3 Professional sehingga peserta didik dapat mengoperasikanya secara mandiri dengan menggunakan komputer, laptop dan lainnya.

Menurut Priwantoro dkk (2018) dalam Puspitasari (2020) Kvisoft flipbook maker pro merupakan suatu software atau aplikasi dalam pembuatan e-book atau buku 
elektronik yang dapat memasukkan file berupa pdf, gambar, video, atau animasi dengan output berupa format exe, html, zip, dan app. software atau aplikasi ini dapat membuat tampilan yang menarik untuk mengubah buku menjadi halaman bolak-balik seperti sebuah buku. Kvisoft flipbook maker digunakan untuk mengubah bahan ajar atau buku menjadi sebuah buku elektronik berbentuk flipbook sebagai media pembelajaran yang berisi animasi, audio, dan navigasi yang menjadi lebih interaktif. Penggunaan flipbook digital ini serupa dengan buku elektronik (e-book) namun kelebihannya flipbook ini dapat dibuka lembar demi lembar yang didukung dengan animasi, video, tulisan, maupun gambar yang relevan dengan konteks buku.

Keunggulan dari aplikasi ini yaitu (1) mampu memberikan modul efek flip atau halaman dapat dibolak-balik; (2) pembuatan modul dengan aplikasi ini sangat mudah; (3) tampilan modul tidak hanya berupa teks dan gambar saja, bentuk audio dan video dapat dikombinasikan dalam menyajikan materi; (4) produk yang dihasilkan dapat dipublikasikan dalam format SWF (Shock Wave Flash), HTML (Hyper Text Markup Language) apabila hendak dipublikasikan melalui website. (Marlina dkk.,2019:425)

Berdasarkan hasil angket analisis kebutuhan yang diberikan kepada siswa kelas XI IPA MAN 2 Jember pada tanggal 14 - 16 Juni 2020 menunjukkan bahwa guru menggunakan metode dalam pembelajaran biologi di dalam kelas adalah $62,7 \%$ presentasi, 18,65 diskusi dan $16,9 \%$ menjawab ceramah, adapun media yang sering digunakan dalam pembelajaran biologi adalah $64,5 \%$ power point sehingga memicu $67,8 \%$ siswa sering merasa mengantuk dan jenuh ketika proses pembelajaran biologi berlangsung. 64,4\% bahan ajar yang digunakan sudah cukup mendukung dalam proses pembelajaran akan tetapi $42,3 \%$ siswa tidak mempunyai pegangan buku lain untuk pelajaran biologi sehingga $93,2 \%$ siswa mencari bahan ajar lain selain buku dari sekolah untuk membantu memahami materi biologi diajarkan. $67,8 \%$ gaya belajar siswa lebih suka membaca dari pada dibacakan dan $61 \%$ siswa setuju $33,9 \%$ siswa sangat setuju jika dikembangkan bahan ajar yang berbasis digital.

Bahan ajar berupa modul digital yang dikembangkan berisi materi sistem koordinasi dan alat indera, sistem reproduksi dan sistem imun yang pada dasarnya dari ketiga materi tersebut bersifat materi yang menuntut penguasaan konsep. Menurut siswa, materi yang membutuhkan tambahan bahan ajar adalah $44,1 \%$ sistem koordinasi dan alat indera, $32,2 \%$ sistem reproduksi dan $23,7 \%$ sistem imun.

Berdasarkan beberapa permasalahan tersebut, maka perlu dikembangkan modul digital dengan harapan dapat menyelesaikan beberapa permasalahan tersebut dan dari hasil penelitian sebelumnya yang dilakukan oleh Asmi (2019)membuktikan bahwasa modul digital dapat membantu proses pembelajaran serta efektif dalam meningkatkan hasil belajar. 


\section{METODE}

Jenis penelitian yang dilakukan merupakan penelitian pengembangan (R\&D) dengan model ADDIE. Penelitian dan pengembangan atau Research and Development (R\&D) adalah strategi atau metode penelitian yang cukup ampuh untuk memperbaiki praktik. Yang dimaksud dengan penelitian dan pengembangan atau Research and Development (R\&D) adalah rangkaian proses atau langkah-langkah dalam rangka mengembangkan suatu produk baru atau menyempurnakan produk yang telah ada agar dapat dipertanggungjawabkan. Produk tersebut tidak selalu berbentuk benda atau perangkat keras (Hardware), seperti buku, modul, alat bantu pembelajaran dikelas atau di laboratorium, tetapi dapat juga perangkat lunak (Software), seperti progam komputer untuk pengolahan data, pembelajaran di kelas, perpustakaan atau laboratorium, ataupun model-model pendidikan, pembelajaran, pelatihan, bimbingan, dan evaluasi, sistem manajemen. (Trianto, 2011).

Model penelitian yang digunakan dalam penelitian kali ini ialah model pengembangan ADDIE. Sehubungan dengan kondisi yang masih berada pada keadaan pandemi covid-19danterbatasnya biaya sehingga tahapan penelitian yang dilakukan sampai tahap development saja, yakni sampai pada uji validitas produk oleh para ahli, yaitu validasi ahli media, validasi ahli materi, dan validasi ahli desain pembelajaran.

Subyek dalam penelitian dan pengembangan ini adalah sebanyak lima orang yang dapat diperinci sebagai berikut, 2 dosen dari Tadris Biologi IAIN Jember, 2 ahli media dan 1 ahli desain pembelajaran.

Prosedur yang dilakukan dalam model pengembangan ADDIE dapat dijelaskan sebagai berikut: tahap pertama yang dilakukan yaitu analisis (Analysis), desain (design), pengembangan (development), implementasi (implementation), dan evaluasi (evaluation) (Sari, 2017). Dalam hal ini, penelitian yang dilakukan di lapangan terdapat penyesuaian dan penyederhanaan tahap pengembangan sehingga tahapan yang dilakukan hanya terdiri dari tahap analisis, desain, dan pengembangan. Sehingga, tidak sampai pada tahap implementasi dan evaluasi karena sampai pada tahap ke tiga ini sudah dapat dihasilkan modul digital yang diinginkan, selain itu kondisi pandemi Covid-19 juga menjadi kendala dalam tahap selanjutnya karena selama masa pandemi tidak diizinkan melakukan pembelajaran tatap muka di sekolah, dengan demikian tahap implementasi dan evaluasi tidak bisa dilaksanakan.

Tahap-tahap pengembangan modul digital yang dilakukan dapat dijabarkan sebagai berikut : 1 . Tahap analisis (analysis) meliputi pelaksanaan analisis kebutuhan dan identifikasi masalah. Kegiatan yang dilakukan pada tahap analisis ini adalah analisis kebutuhan (need analysis) berupa menganalisis karakteristik materi pembelajaran yang relevan, serta menganalisis ketercukupan atau kuantitas bahan ajar yang tersedia. Sementara dari segi permasalahan pembelajaran dilakukan analisis terhadap berbagai 
permasalahan pembelajaran terutama yang terkait dengan strategi pembelajaran, dan kondisi kegiatan belajar mengajar. Tahap analisis dilaksanakan pada bulan Juni 2020 di MAN 2 Jember. 2. Tahap desain (design), pada tahapan desain dilakukan beberapa hal yang meliputi perumusan tujuan pembelajaran yang diharapkan, menentukan materi atau pokok bahasan yang akan dipelajari. Selanjutnya dilakukan penyusunan produk dengan sistematika yang disesuaikan dengan kebutuhan peserta didik, dan kemudian menuliskan isi dari produk tersebut berdasarkan kriteria-kriteria penyusunan produk yang baik.3. Tahap pengembangan (development) meliputi penyiapan dan penulisan materi pada produk yang disesuaikan dengan kebutuhan peserta didik dalam melakukan kegiatan belajar.

Instrumen pengumpulan data yang digunakan dalam penelitian yakni angket validasi yang digunakan untuk mengukur tingkat kelayakan produk bahan ajar berupa modul digital yang dikembangkan. Angket yang digunakan dalam penelitian ini berbentuk checklist dengan penilaian skor pada setiap aspek menggunakan skala likert 1-5 (Sahlan, 2015).

Setelah diperoleh data penelitian, maka langkah selanjutnya yaitu analisis data. Data yang diperoleh dari lembar validasi akan dianalisis dengan menggunakan teknik analisis presentase. Rumus pengolahan data setiap aspek yang dinilai oleh validator sebagai berikut :

$$
P=\frac{X i}{X} x 100 \%
$$

\section{Keterangan}

$\mathbf{P}=$ nilai presentase

$\mathbf{X} \mathbf{i}=$ jumlah skor yang diberikan validator untuk masing-masing aspek

$\mathbf{X}=$ skor maksimun untuk setiap kriteria Selanjutnya seluruh data presentase penilaianyang diperoleh diubah menjadi data kuantitatif deskriptif yang menggunakan kriteria validitas. Kriteria kualitas media pembelajaran modul digital dapat dilihat pada Tabel 1 berikut.

Tabel 1. Kriteria Kualitas Modul Digital Biologi

\begin{tabular}{|c|c|c|c|}
\hline No & Nilai & Kriteria & Keterangan \\
\hline 1 & $81-100 \%$ & Sangat valid & $\begin{array}{l}\text { Sangat valid, } \\
\text { tidak revisi }\end{array}$ \\
\hline 2 & $61-80 \%$ & Valid & $\begin{array}{l}\text { Valid, tidak } \\
\text { revisi }\end{array}$ \\
\hline 3 & $41-60 \%$ & Cukup valid & $\begin{array}{l}\text { Kurang valid, } \\
\text { revisi }\end{array}$ \\
\hline 4 & $<40 \%$ & Tidak valid & $\begin{array}{c}\text { Tidak valid, } \\
\text { revisi }\end{array}$ \\
\hline
\end{tabular}

\section{HASIL DAN PEMBAHASAN}

Berdasarkan metode penelitian dan pengembangan yang telah disusun oleh peneliti, tahap pengembangan yang dilakukan hanya meliputi tiga tahapan pengembangan yaitu analisis (analysis), desain (design), dan pengembangan (development). Hal ini dikarenakan tahap impleentasi dan evaluasi tidak dapat dilakukan karena adanya pandemi covid-19 yang tidak memungkinkan dilakukannya pembelajaran tatap muka di kelas, sehingga kegiatan implementasi dan evaluasi tidak dapat dilaksanakan.

Pada tahapan analisis dilakukan analisis kebutuhan dan identifikasi masalah, berdasarkan angket analisis kebutuhan yang disebarkan kepada siswa kelas XI IPA MAN 2 Jember pada tanggal 14-16 Juni 2020 diketahui bahwa 64,4\% 
bahan ajar yang digunakan sudah cukup mendukung dalam proses pembelajaran akan tetapi $42,3 \%$ siswa tidak mempunyai pegangan buku lain untuk pelajaran biologi sehingga 93,2\% siswa mencari bahan ajar lain selain buku dari sekolah untuk membantu memahami materi biologi diajarkan. 67,8\% gaya belajar siswa lebih suka membaca dari pada dibacakan dan $61 \%$ siswa setuju 33,9\% siswa sangat setuju jika dikembangkan bahan ajar yang berbasis digital. Bahan ajar ini berisi materi sistem koordinasi dan alat indera, sistem reproduksi dan sistem imun yang pada dasarnya dari ketiga materi tersebut bersifat materi konsep, menurut siswa materi yang membutuhkan tambahan bahan ajar adalah 44,1\% sistem koordinasi dan alat indera, 32,2\% sistem reproduksi dan $23,7 \%$ sistem imun.

Berdasarkan hasil identifikasi masalah, yang diperoleh dari hasil angket online yang disebarkan kepada siswa kelas XI IPA MAN 2 Jember pada tanggal 14-22 Juni 2020 dapat diketahui bahwa dalam pembelajaran di kelas, 62,7\% dilakukan presentasi, 18,65 diskusi dan 16,9\% ceramah/klasikal, adapun media yang sering digunakan dalam pembelajaran biologi adalah $64,5 \%$ power point sehingga memicu $67,8 \%$ siswa sering merasa mengantuk dan jenuh ketika proses pembelajaran biologi berlangsung.

Setelah tahap analisis selesai, dilanjutkan pada tahap selanjutnya, yaitu tahap desain, pada tahapan ini dilakukan beberapa kegiatan, antara lain merumuskan tujuan pembelajaran, menentukan materi atau pokok bahasan yang akan dipelajari. Selanjutnya dilakukan penyusunan produk dengan sistematika yang disesuaikan dengan kebutuhan peserta didik, dan kemudian menuliskan isi dari produk tersebut berdasarkan kriteria-kriteria penyusunan produk yang baik.

Pada tahap perumusan tujuan pembelajaran, perumusan tujuan pembelajaran ini disesuaikan dengan indikator yang telah dibuat berdasarkan analisis KI (Kompetensi Inti) dan KD (Kompetensi Dasar) dalam kurikulum 2013 pada materi sistem koordinasi dan alat indera, sistem reproduksi, dan sistem imun.

Setelah dilakukan perumusan tujuan pembelajaran selesai, dilanjutkan dengan perencanaan penyajian materi. Pada tahap ini, materi yang dikembangkan adalah sistem koordinasi dan alat indera, sistem reproduksi dan sistem imun yang diambil dari berbagai referensi seperti buku paket kelas XI, dan penentuan materi ini berdasarkan kebutuhan siswa. Latihan soal yang dicantumkan berupa soal yang sesuai dengan indikator yang dicapai dan terdapat beberapa soal yang diadaptasi dari soal UN sebelumnya. Penyajian modul digital ini disesuaikan dengan Kompetensi Inti dan Kompetensi Dasar yang ditetapkan di sekolah.

Tahapan selanjutnya yaitu penyusunan desain modul digital. Modul digital didesaindandikembangkanmenggunakan aplikasi Kvisoft Flipbook Maker Pro 4.2.2.0. Penyusunan desain modul digital yaitu dengan menyusun kerangka yang terdiri dari cover, kata pengantar, daftar isi, petunjuk penggunaan simbol, KI dan 
$\mathrm{KD}$, materi, evaluasi, daftar pustaka, dan profil penyusun. Aplikasi Adobe Flash CS3 Professional merupakan software tambahan yang digunakan untuk mengembangkan bagian evaluasi. Berikut dapat disajikan desain modul digital yang dikembangkan peneliti.

Setelah menyelesaikan tahap desain, langkah selanjutnya dilanjutkan dengan tahap pengembangan. Adapun langkahlangkah yang dilakukan dalam tahap pengembangan diantaranya sebagai berikut;

a. Mempersiapkan materi, gambar, video, contoh soal dan latihan yang akan di import ke dalam modul digital.

b. Pembuatan file tahap pertama menggunakan Microsoft Word, kemudian tahap kedua mendesain background, ketiga import file dalam bentuk PDF.

c. Pembuatan file yang berisi latihan soal menggunakan Adobe Flash Professional CS3 yang di export dalam bentuk swf.

d. Memasukkan file pdf dan swf kedalam aplikasi Kvisoft Flipbook Maker pro 4.2.2.0.

e. Menyimpan atau mengexport file modul digital dengan berekstensi exe.

Jika langkah di atas telah selesai, maka modul digital yang dibuat telah siap dibuka dalam bentuk flip (bolak-balik) dan digunakan. Berikut dapat dijabarkan modul digital yang dikembangkan oleh peneliti dalam Tabel. 2. Draf Modul Digital.

f. Setelah proses pembuatan modul Tabel 2. Draft modul digital
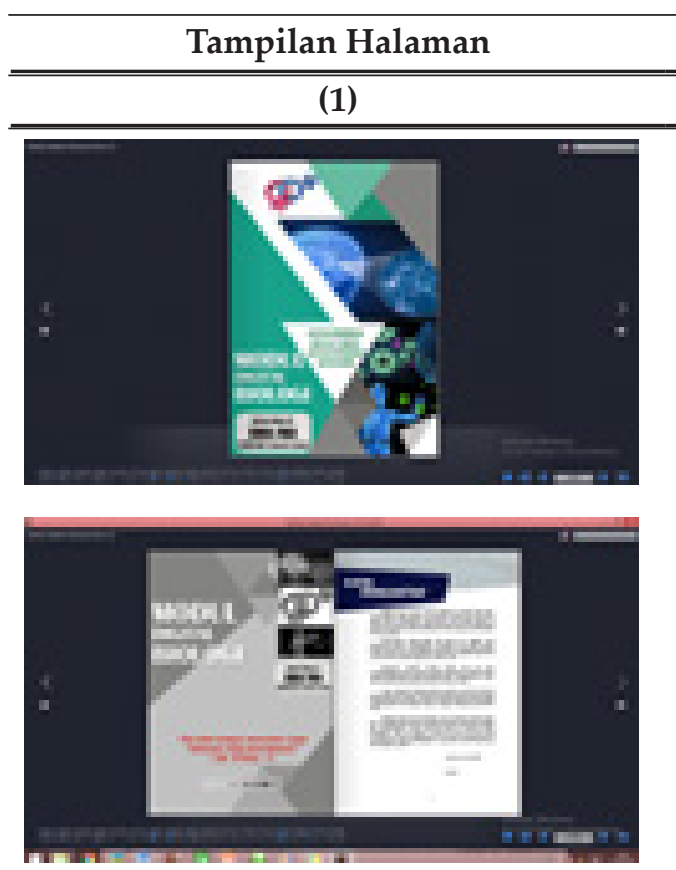

Halaman ini berisi cover dalam dan kata pengantar

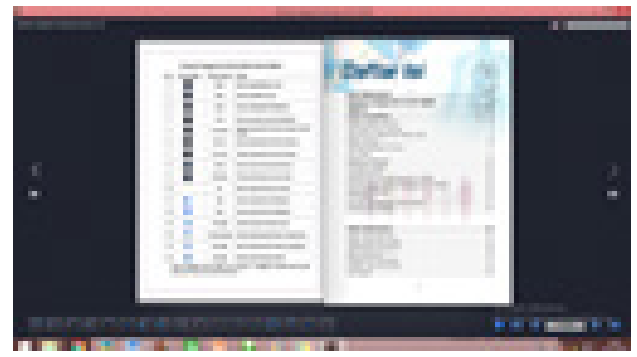

Pada halaman ini berisi petunjuk penggunaan simbol dan daftar isi 

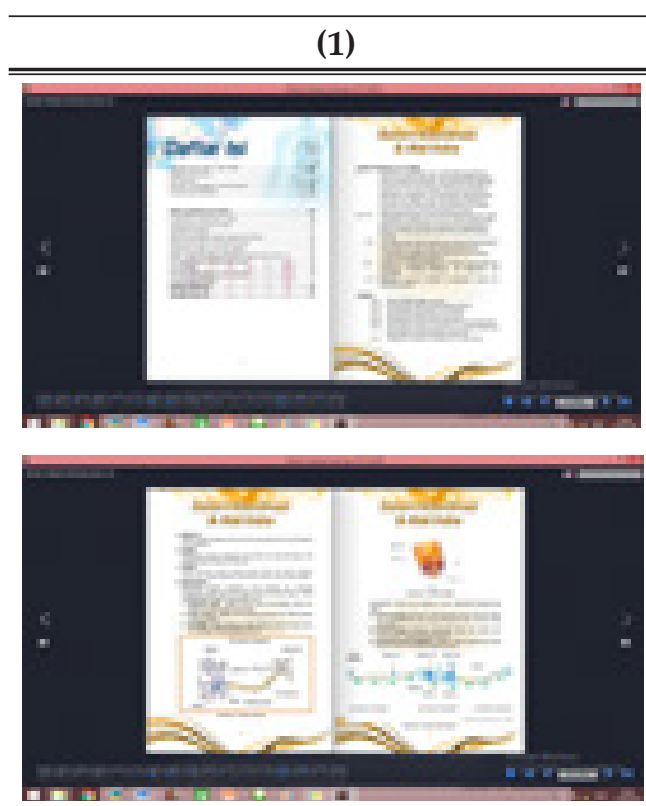

Halaman ini berisi materi

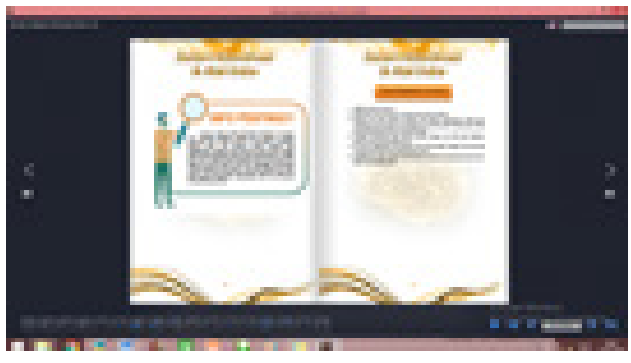

Pada halaman ini berisi info penting dan petunjuk mengisi lembar soal evaluasi

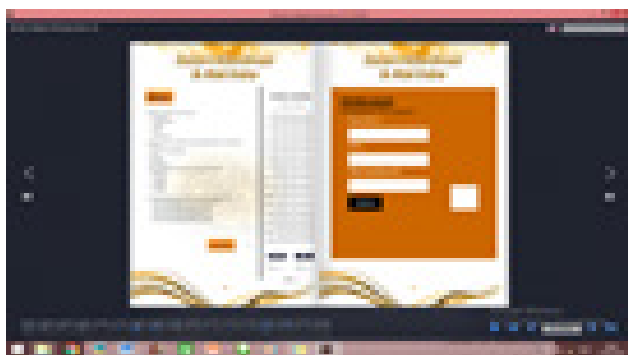

Halaman ini berisi soal evaluasi beserta jawabanya dan berisi penilaian yang jika di klik submit akan muncul nama, kelas dan nilai yang dicapai

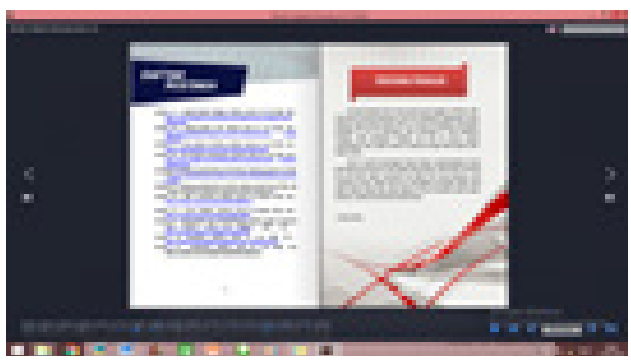

Halaman ini berisi daftar pustaka dan berisi biodata penulis

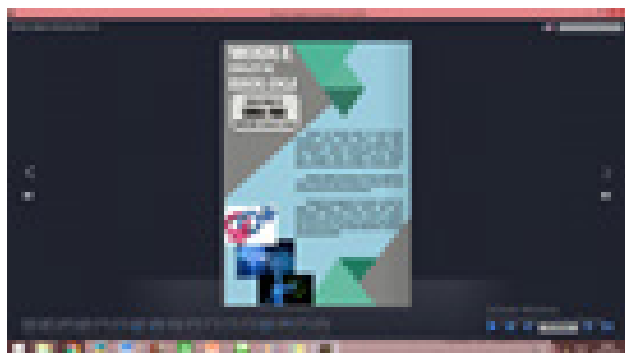

Halaman ini termasuk halaman terakhir yang berisi cover belakang 
Indonesian Journal of Mathematics and Natural Science Education, 2 (1), 2021

Imro'atul Khasanah, Ira Nurmawati

digital sudah selesai, langkah selanjutnya adalah penelaah dosen pembimbing.

g. Analisis dan revisi I

h. Validasi.

Validasi dilakukan dengan tujuan untuk mengkonsultasikan tentang bahan ajar yang dikembangkan kepada para ahli (dosen). Validasi adalah mengisi lembar instrumen yang terkait dengan ahlinya, yaitu ahli media, ahli materi dan ahli desain pembelajaran. Pengembangan ini sampai uji validitas saja karena keterbatasan waktu dan biaya yang dimiliki oleh peneliti serta keadaan dalam situasi pandemi Covid-19.

Pada tahap validasi ini, dilakukan oleh validator ahli media, validator ahli materi, dan validator desain pembelajaran. Adapun hasilnya dapat dirincikan pada tabel 3 dan tabel 4.

Validasi pertama dilakukan oleh ahli materi. Validator ahli materi dilakukan oleh dosen matakuliah Anatomi Fisiologi Manusia, Ibu Yanti Nurhayati, S.kep. Ns.MMRS sebagai validator pertama (V1) dan dosen Tarbiyah dan Ilmu Keguruan matakuliah Fisiologi Tumbuhan, Ibu Heni Setyawati, M.Si sebagai validator kedua (V2). Validator ahli materi adalah untuk menilai aspek kelayakan isi, aspek kelayakan penyajian dan aspek penilaian bahasa. Hasil validasi oleh ahli materi dapat disajikan pada Tabel. 3.

Berdasarkan Tabel. 3 diketahui bahwa hasil validasi ahli materi didapatkan rata-rata seluruh aspek dari validator ahli materi sebesar 97,35\%, berdasarkan kriteria validitas yang digunakan bahwa
Tabel 3. Persentase skor rata-rata hasil uji validitas ahli materi

\begin{tabular}{clr}
\hline No & \multicolumn{1}{c}{ Aspek yang dinilai } & $\begin{array}{c}\text { Persentase } \\
\text { rata-rata skor }\end{array}$ \\
\hline 1 & Kesesuaian materi dengan & $90,0 \%$ \\
& KI dan KD & \\
2 & Keakuratan materi & $98,5 \%$ \\
3 & Kemutakhiran materi & $100,0 \%$ \\
4 & Mendorong keingintahuan & $90,0 \%$ \\
5 & Teknik penyajian & $100,0 \%$ \\
6 & Pendukung penyajian & $100,0 \%$ \\
7 & Penyajian pembelajaran & $95,0 \%$ \\
8 & Koherensi dan keruntutan & $100,0 \%$ \\
& alur piker & $100,0 \%$ \\
9 & Kesesuaian bahasa dengan & \\
& kaidah bahasa indonesia & \\
& yang baik dan benar & $100,0 \%$ \\
10 & Keterbacaan dan kekomuni- & \\
& katifan & $\mathbf{9 7 , 3 5 \%}$ \\
\hline
\end{tabular}

nilai tersebut dikategorikan sangat valid dan tidak perlu direvisi, dengan demikian dapat disimpulkan bahwa bahan ajar modul digital layak digunakan dalam pembelajaran.

Setelah dilakukan validasi oleh ahli materi, maka dilanjutkan pada tahap validasi oleh ahli media. Validator ahli media dilakukan oleh dosen Tarbiyah dan Ilmu Keguruan matakuliah pengembangan bahan ajar, Bapak Dr. A. Suhardi, ST., M.Pd sebagai validator pertama (V1) dan dosen Tarbiyah dan Ilmu Keguruan bidang keahlian Teknologi Pembelajaran yaitu Bapak Dr. Moh. Sahlan, M.Ag sebagai validator kedua (V2). Validator ahli media adalah untuk menilai aspek penilaian kelayakan kegrafikan dan aspek penilaian kelayakan bahasa. Penyajian data kuantitatif yang diperoleh dari validasi 1 dan validasi 2 dapat dilihat pada Tabel 4.

Berdasarkan hasil validasi ahli media yang tercantum pada Tabel 4. didapatkan 
Tabel 4. Persentase skor rata-rata hasil uji validitas ahli media

\begin{tabular}{llc}
\hline No & \multicolumn{1}{c}{ Aspek yang dinilai } & $\begin{array}{c}\text { Persentase } \\
\text { rata-rata skor }\end{array}$ \\
\hline 1 & Ukuran modul & $90,0 \%$ \\
2 & Design sampul modul & $85,0 \%$ \\
3 & Design isi modul & $90,5 \%$ \\
4 & Lugas & $83,5 \%$ \\
5 & Komunikatif & $90,0 \%$ \\
6 & Dialogis dan interaktif & $90,0 \%$ \\
7 & Kesuaian dengan perkem- & $90,0 \%$ \\
& bangan peserta didik & $90,0 \%$ \\
8 & $\begin{array}{l}\text { Kesesuaian dengan kaidah } \\
\text { bahasa }\end{array}$ & $95,0 \%$ \\
9 & $\begin{array}{l}\text { Penggunaan istilah, simbol } \\
\text { atau ikon }\end{array}$ & $95,0 \%$ \\
\hline & Rata-rata & $\mathbf{8 9 , 0}$ \\
\hline
\end{tabular}

rata-rata seluruh aspek dari validator ahli media sebesar $89 \%$, berdasarkan kriteria validitas yang digunakan bahwa nilai tersebut dikategorikan sangat valid dan tidak perlu revisi, dengan demikian modul digital layak digunakan dalam pembelajaran.

Validasi ke tiga, yaitu validasi oleh ahli desain pembelajaran, adapun hasil validasi oleh ahli desain pembelajaran Validator ahli desain pembelajaran dilakukan oleh dosen Tarbiyah dan Ilmu Keguruan yaitu Ibu Dr. Dyah Nawangsari, M.Ag sebagai validator. Validator ahli desain pembelajaranadalah untuk menilai aspek design pembelajaran dan aspek karakteristik modul. Penyajian data kuantitatif yang diperoleh dari validasi ahli desain pembelajaran dapat dilihat pada Tabel 5 .

Berdasarkan data pada Tabel 5. dapat diketahui bahwa hasil validasi ahli desain pembelajaran didapatkan rata-rata seluruh aspek dari validator ahli desain pembelajaran sebesar 80,5\%, berdasarkan kriteria validitas yang digunakan bahwa nilai tersebut dikategorikan valid dan
Tabel 5. Presentase skor rata-rata hasil uji validitas ahli desain pembelajaran

\begin{tabular}{llc}
\hline No & \multicolumn{1}{c}{ Aspek yang dinilai } & $\begin{array}{c}\text { Persentase } \\
\text { rata-rata skor }\end{array}$ \\
\hline 1 & Aspek desain pembelajaran & $78,5 \%$ \\
2 & Aspek karakteristik modul & $83,5 \%$ \\
\hline Rata-rata & $\mathbf{8 0 , 5 \%}$ \\
\hline
\end{tabular}

tidak perlu revisi, dengan demikian dapat dikatakan bahwa modul digital layak digunakan dalam pembelajaran.

\section{SIMPULAN}

1. Dalam proses pengembangan modul digital sebagai bahan ajar siswa kelas XI ini dilakukan dalam beberapa tahapan yaitu analisis (Analysis), perancangan (Design), pengembangan (Development), karena keterbatasan biaya dan waktu peneliti, serta kondisi yang berada dalam situasi pandemi Covid-19, sehingga tahap implementasi dan evaluasi tidak dapat dilakukan.

2. Validasi terhadap modul digital sebagai bahan ajar siswa kelas XI dilakukan oleh 2 ahli materi yaitu Yanti Nurhayati, S.kep.Ns.MMRS sebagai validator pertama (V1), Heni Setyawati, M.Si sebagai validator kedua (V2), 2 ahli media yaitu Dr. A. Suhardi, ST.,M.Pd sebagai validator pertama (V1) dan Dr. Moh. Sahlan, M.Ag sebagai validator kedua(V2). dan 1 ahli desain pembelajaran Dr. Dyah Nawangsari, M.Ag sebagai validator desain pembelajaran. Hasil validasi ahli materi didapatkan rata-rata dari keseluruhan aspek dari validator ahli materi sebesar 97,35\%, ahli media sebesar $89 \%$, ahli desain pembelajaran sebesar 80,5\%, berdasarkan kriteria 
validitas yang digunakan bahwa nilai tersebut dikategorikan sangat valid dan tidak perlu revisi, dengan demikian dapat dikatakan bahwa bahan ajar modul digital layak digunakan dalam pembelajaran.

3. Adapun kelebihan dan kelemahan bahan ajar berupa modul digital sebagai berikut:

4. Kelebihan: menambah referensi bahan ajar berupa modul digital dalam proses belajar mengajar, menghemat biaya peserta didik dengan berbasis digital dan menghemat penggunaan kertas, terhindar dari rusaknya bahan ajar seperti buku paket atau lks, dapat digunakan dimana saja dan kapan saja. Selain kelebihan modul digital ini memiliki kekurangan yaitu: bahan ajar modul digital ini dapat diakses hanya menggunakan laptop dan komputer, modul digital ini berbentuk soft file tetapi belum sampai pada tahap publish internet sehingga tidak semua bisa mengakses modul digital dengan menggunakan kvisoft flipbook maker pro ini pada internet yang tersedia, dan audio video tumpang tindih.

\section{DAFTAR PUSTAKA}

Asmi, Adhtya Rol. (2018). Pengembangan E-Modul Berbasis Flip Book Maker Materi Pendidikan Karakter untuk Pembelajaran Mata Kuliah Pancasila MPK Universitas Sriwijaya. Jurnal Pendidikan Ilmu Sosial. Volume 27.

Marlina. (2019). Development Of Electronic Module: Student Learning Motivation Using The Application Of Ethnoconstructivism-Based Flipbook Kvisoft. Jurnal Pedagogik. Vol. 06 No. 02.

Pane, Aprida dan Muhammad Darwis
Dasopang. (2017). Belajar dan Pembelajaran. Fitrah Jurnal kajian ilmu-ilmu keislaman. Vol. 03 No.2. e-ISSN:2460-2345, p-ISSN:2442-6997.

Prawiradilaga, Dewi Salma dan Uwes Anis Chaeruman.(2018). Modul Hypercontent Teknologi Kerja (Perfomance Technology). Jakarta: Kencana.

Puspitasari, Anggraini Diah. (2019). Penerapan Media Pembelajaran Fisika Menggunakan Modul Cetak Dan Modul Elektronik Pada Siswa SMA. Jurnal Pendidikan Fisika. Vol. 7 No. 1.

Rahardi. (2005). Panduan lengkap menulis artikel, feature dan esai. Jakarta: PT. Kawan Pustaka.

Ramadhani, Rizki Yulia. Ramdhani Masrul, Rahmi. Rani Rahim. Andi Febriana Tamrin. Juliana Santy Daulay. Anita Purba. Pasaribu Tasnim, Arsen Nahum. Muhammad Asdar AB. Tuti Agustin. Cahyo Prianto. Janner Simarmata. (2020). Metode dan Teknik Pembelajaran Inovatif. Medan: Yayasan Kita Menulis.

Sahlan, Moh. (2015). Evaluasi Pembelajaran. Jember: STAIN Jember Press.

Sari, Bintari Kartika. (2017). Design Pembelajaran Model ADDIE dan Implementasinya dengan Teknik Jigsaw. Prosiding Seminar Nasional Pendidikan: Tema Design Pembelajaran di Era ASEAN Economic Community (AEC) untuk Pendidikan Indonesia Berkemajuan. Fakultas Keguruan dan Ilmu Pendidikan University Muhammadiyah Sidoarjo. ISBN 978602-70216-2-4.

Trianto. (2011). Pengantar Penelitian Pendidikan Bagi Pengembangan Profesi Pendididkan \& Tenaga Kependidikan. Jakarta: Prenada Media Grup.

\section{PROFIL SINGKAT}

Penulis pertama lahir di Jember, 12 Oktober 1997. Menempuh pendidikan S1 Tadris Biologi FTIK IAIN Jember dan lulus pada Januari 2021. Setelah lulus sampai sekarang, penulis aktif mengabdi di salah satu pondok pesantren di Jember. 